\title{
Study on Adoption Behaviour of Improved Onion Production Technology of Onion Growers in Alirajpur District in M.P.
}

\author{
Laxmi Tagor $^{1}$, Dipika Dhakad ${ }^{1}$, Dr. Sandhya Choudhary ${ }^{2}$, Dr. V.K. Swarnakar ${ }^{3}$ \\ ${ }^{1}$ M.Sc. Students 2016, College of Agriculture, Indore \\ ${ }^{2}$ Associate Professor, Extension EducationCollege of Agriculture, Indore \\ ${ }^{3}$ Professor \& Head of Extension Education, College of Agriculture, Indore
}

\begin{abstract}
Alirajpur district in Madhya Pradesh is one of the important areas with great potential for onion production. In district Alirajpur, onion is grown in an area of 1370 hectares with a production of 20550 tonnes, with a maximum productivity of 15.00 tonnes per hectare. It was found that the majority of the farmers are still lagging behind the adoption of improved onion production technology in the area. It thus, becomes necessary to assess the adoption behaviour of onion growers, towards improved onion production technology therefore the 130 farmers were selected using proportionate allocation method from small, medium and large farmers. This study depicted that majority of the onion growers 37.69 per cent were found to have medium adoption behaviour of overall technology followed by high adoption behaviour 36.15 per cent and low adoption behaviour 26.15 per cent in respect of overall onion production technology respectively
\end{abstract}

\section{Introduction}

Vegetables are grown in almost all the states in the country under varied agro-climatic, soil conditions and various adoption levels of improved production technology. Onion is one of the important horticultural crops that enhance the farmers' economy with agricultural development which plays a vital role in Indian economy. It is well known fact that the improved farming strategy calls for the adoption of balanced and efficient use of modern inputs and techniques for profitable and increase in production. The use of modern technology needs a careful management of resources before allocating the area under this commercial crop. Farmers are now well aware of improved production technology of onion, for minimizing the risk factor and adoption of modern technology on their farm. Many studies showed that wide gap exists between the available production technology of onion and its actual application on the farmers' field which is reflected through poor yield. Studies also showed there is a tremendous opportunity for increasing the production of onion by adoption of improved onion production technology. To achieve the higher level of production and productivity, the low level of adoption of improved onion production technology may be a big hindrance, which hampers the production potential of onion on farmers' field. Alirajpur district in Madhya Pradesh is one of the important areas with great potential for onion production. In district Alirajpur, onion is grown in an area of 1370 hectares with a production of 20550 tonnes, with a maximum productivity of 15.00 tonnes per hectare. It was found that the majority of the farmers are still lagging behind the adoption of improved onion production technology in the area. It thus, becomes necessary to assess the adoption behaviour of onion growers, towards improved onion production technology with following objectives.

Objective-

To measure the adoption behavior of onion growers towards improved production technology

\section{Review Of Literature}

Chandrashekhar (2007) reported that 40 per cent of the respondents belonged to medium category followed by 36.66 per cent and 23.33 per cent of the respondents belonging to high and low adoption categories respectively. Hence, the probable reason for majority of the respondents to fall under medium adoption category might be due to the medium to high knowledge possessed by majority of the respondents. Solanki (2009) stated that vegetable growers were found to adopt the various components of vegetable production in varying degree. The overall adoption behaviour of respondents regarding improved vegetable production technology shows that majority of the respondents i.e. 47.27 percent had medium adoption behaviour followed by 31.83 percent had low and 20.90 percent respondents had high adoption behavior. Agarwal (2013) reported that majority of the onion growers 37.69 per cent found to medium adoption behaviour followed by high adoption behaviour 36.15 per cent and low adoption behaviour 26.15 per cent in respect of onion production technology respectively. 


\section{Material \& Methods}

The data was collected with the help of interview schedule, which was prepared on the basis of objectives of the study. For the convenience of data collection, the interview schedule was prepared in Hindi. Before the actual collection of the data the interview schedule was subjected to pre-testing. The data was collected personally by the researcher through a well structured and pre-tested interview schedule. The researcher personally met the respondents and explained to them about the purpose of the study. After establishing rapport with the respondents they were interviewed and their responses recorded in the interview schedule. Multi stage sampling technique was used for selection of block in the district, villages in the selected block and onion growers in the selected villages. From the list of onion growers of selected five villages was prepared. These farmers were categorized into 3 size groups i.e. small farmers $(<2$ ha.), medium farmers $(2.1$ 4.00 ha.) and large farmers (>4.1 ha). From this list 130 onion growers were selected randomly using proportional allocation

\section{Adoption behaviour of onion growers:-}

The extent of adoption of onion production technology refers to the extent of adoption of recommended and improved onion production techniques and practices by onion growers on their farm. Extent of adoption of onion production technology was measured with the help of index developed as per schedule. Over all 12 components of onion production technology was included in the schedule to test the adoption behaviour of onion growers. The answers elicited from the farmers was compared with correct answer and quantified by giving " 1 " score for adoption and " 0 " for non adoption. Based on the total scores, the respondents were grouped into three categories as low, medium and high by using mean and standard deviation as a measure of check. Finally this raw adoption score obtained by individual respondent was converted into adoption index as below: Sum of the adoption scores obtained by respondent

Adoption index $=$ -
Sum of obtainable adoption score

Result \& Discussion-

Adoption behaviour of onion growers.

Adoption behaviour tends to be specific to particular innovation, individuals, and environment. Farmer's incentives and disincentives to adopt particular technology are determined by his personal belief about its value and permissiveness of his environment. So adoption of an innovation varies not only from area to area but also from farmer to farmer with their socio-personal, economic and psychological characteristics. At earlier the socio economic and psychological characteristics of onion growers are discussed and in present section the adoption behaviour of onion growers towards improved production technology is described. With the recommendation of improved onion production technology a great emphasis is being paid by both the scientists and extension workers to boost up onion production. The various experimentation and researches have predicted means and measures for high production of onion at field level. The efficient use of recommended technology to their preferences undoubtedly will able the potential users to enhance the onion production, which in tern could improve the economic status of the onion growers. This seems possible only when the onion growers adopt the recommended onion production technology according to their preferences. The adoption pattern of onion growers towards improved onion production technology was presented in table.

Table: Adoption behaviour of extant of adoption onion growers towards improved production technology.

\begin{tabular}{|c|c|c|c|c|}
\hline \multicolumn{5}{|c|}{$(n=130)$} \\
\hline S.No. & Practices & Frequency of adoption & $\begin{array}{c}\text { Percentage to } \\
\text { total }\end{array}$ & Rank \\
\hline 1 & Method of field preparation & 106 & 81.54 & $\mathbf{I}^{\text {st }}$ \\
\hline 2 & Method of nursery management & 96 & 73.85 & $\mathbf{V}^{\text {th }}$ \\
\hline 3 & Variety/Hybrid & 95 & 73.08 & $V I^{\text {th }}$ \\
\hline 4 & Seed rate & 98 & 75.38 & III $^{\text {rd }}$ \\
\hline 5 & Seed treatment & 96 & 73.85 & $\mathbf{V}^{\text {th }}$ \\
\hline 6 & Method of transplanting & 88 & 67.69 & IX $^{\text {th }}$ \\
\hline 7 & FYM/Bio fertilizer application & 94 & 72.31 & $\mathrm{VII}^{\text {th }}$ \\
\hline 8 & Fertilizers (NPK) & 93 & 71.54 & VIII $^{\text {th }}$ \\
\hline 9 & Intercultural operations & 95 & 73.08 & $\mathrm{VI}^{\text {th }}$ \\
\hline 10. & $\begin{array}{l}\text { Irrigation } \\
\end{array}$ & 101 & 77.69 & II $^{\text {nd }}$ \\
\hline 11. & Plant Protection Measures & 97 & 74.62 & IV $\mathbf{V}^{\text {th }}$ \\
\hline 12. & Proper method of digging & 93 & 71.54 & VIII $^{\text {th }}$ \\
\hline 13. & Average adoption & 96 & 73.85 & \\
\hline
\end{tabular}


The data given in the table showed that, on an average 73.85 per cent recommended onion production technology was adopted by onion growers in study area. Study also assessed the frequency of adoption of onion growers about the each components of onion production technology. There were 12 components of onion production technology considered in study and the onion growers were assessed as per their adoption behaviour in respect to each component of onion production technology. It is evident from the data that the adoption level of onion growers on the basis of total score obtained by them was found to "method of field preparation" (rank $\mathrm{I}^{\text {st }}$ ) adopted by 81.54 per cent onion growers followed by "irrigation" (rank II ${ }^{\text {nd }}$ ) adopted by 77.69 per cent onion growers, "seed rate" (rank III $\left.{ }^{\text {rd }}\right)$ adopted by 75.38 per cent onion growers, "plant protection measure" $\left(\right.$ rank IV $\left.^{\text {th }}\right)$ adopted by 74.62 per cent onion growers, "method of nursery management" and "seed treatment" (rank $\mathrm{V}^{\text {th }}$ each) adopted by 73.85 per cent onion growers, "variety/hybrid" and "intercultural operations" (rank VI ${ }^{\text {th }}$ each) adopted by 73.08 per cent onion growers, "FYM/Bio fertilizer application" (rank VII ${ }^{\text {th }}$ ) adopted by 72.81 per cent onion growers, "fertilizer (NPK)" and "proper method of digging" (rank VIII ${ }^{\text {th }}$ each) adopted by 71.54 per cent onion growers and "method of transplanting" (rank IX ${ }^{\text {th }}$ ) adopted by 67.69 per cent onion growers respectively. It is pertinent to have an idea to assess the aggregate adoption level of onion growers in respect of onion production technology on their farm that would be showed the total picture of adoption behaviour. Hence, it is calculated and the distribution of onion growers have been made according to their extent of adoption regarding overall onion production technology as aggregate was presented in table below-

Table: Distribution of onion growers according to overall onion production technology.

\begin{tabular}{|c|c|c|c|}
\hline S.No. & Categories & Frequency & Percentage \\
\hline 1. & Low & 34 & $\mathbf{2 6 . 1 5}$ \\
\hline 2. & Medium & 49 & $\mathbf{3 7 . 6 9}$ \\
\hline 3. & High & 47 & $\mathbf{3 6 . 1 6}$ \\
\hline & Total & $\mathbf{1 3 0}$ & $\mathbf{1 0 0 . 0 0}$ \\
\hline
\end{tabular}

$(\mathrm{n}=130)$

The data presented in table showed that majority of the onion growers 37.69 per cent found to medium adoption behaviour of overall technology followed by high adoption behaviour 36.16 per cent and low adoption behaviour 26.15 per cent in respect of overall onion production technology respectively. Thus, it can be concluded that in study area, most of the onion growers were found to medium adoption behaviour of overall technology of onion production followed by high and low adoption.

Fig:14: Distribution of onion growers according to overall onion production technology

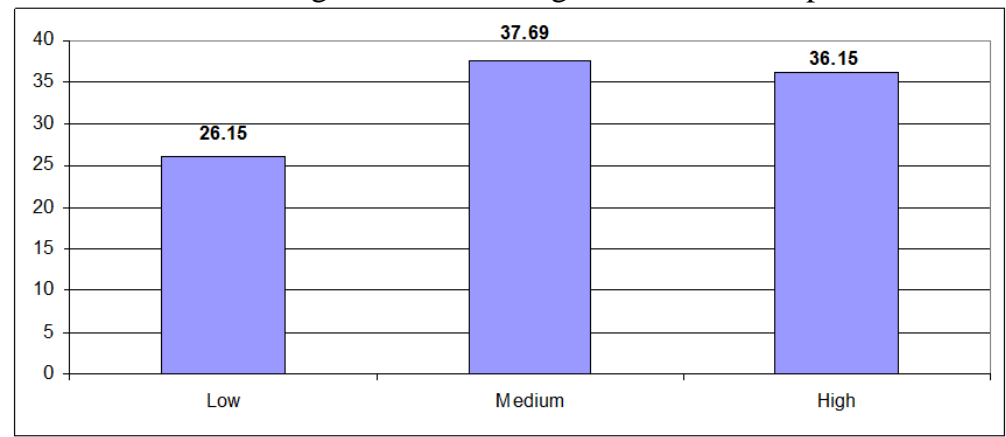

Adoption behavior of onion growers towards improved production technology:

It can be clear from the result of the study that the most of the onion growers were found to have medium adoption behaviour of overall technology of onion production followed by high and low adoption. The situation revealed that the respondents were average in adoption of improved onion production technology. This might be due to the fact that, onion growers had the tendency towards indiscriminate use of inputs inefficiently, lack of technical skill and lack of faith in result of these improved practices and technology. The prime reason for medium adoption of onion production technology was also high cost of inputs and uncertainty in market return. This finding is in conformity with the findings as reported by Meena et al. (2005), Raghavendra (2005), Chandrashekhar (2007), Solanki (2009) and Agarwal (2013) 


\section{References}

[1] Agarwal, Neha (2013). A study on adoption behaviour of onion growers in relation to their socio-economic and psycho characteristics in Sehore district, Madhya Pradesh. M.Sc (Ag.) Thesis Submitted to Rajmata Vijayaraje Scindia Krishi Vishwa Vidyalaya, Gwalior.

[2] Chandrashekhar,S.K. (2007). Analysis of onion production and marketing behaviour of farmers in Gadag District, Karnataka. M.Sc.(Agi) Thesis submitted to University of Agricultural Sciences, Dharwad.

[3] Meena,K.C.; Babel,K.S. and Meena,H.R. (2005). Adoption of improve practices of cabbage growing farmers. Indian J. Extn.Edu. 6(1):31-32.

[4] Pandey,U.B. (2000). Strategy for increasing onion productivity and minimizing post-harvest losses in onion in Andhra Pradesh. News Letter National Horticultural Research and Development Foundation. 20(1\&4):1-5.

[5] Patel, Alkesh (2009). Profitability and resource use efficiency of onion production in Khargone district of Madhya Pradesh. M.Sc (Ag.) Thesis Submitted to Jawaharlal Nehru Krishi Vishwa Vidyalaya, Jabalpur.

[6] Raghavendra,R. (2005). Knowledge and adoption of recommended cultivation practices of cauliflower growers in Belgaum District of Karnataka. M.Sc.(Agi) Thesis submitted to University of Agricultural Sciences, Dharwad

[7] Solanki,D.L (2009). A study on adoption behaviour of vegetable growers in relation to their socio-economic and psycho characteristics in Khandwa district of Madhya Pradesh. M.Sc.(Ag.) Thesis, submitted to R.A.K. College of Agriculture, Sehore (M.P.). 